\title{
Blurring the joint line? Urban life on the edge between old and new in Shanghai
}

DOI:

10.1057/udi.2008.9

\section{Document Version}

Accepted author manuscript

Link to publication record in Manchester Research Explorer

\section{Citation for published version (APA):}

lossifova, D. (2009). Blurring the joint line? Urban life on the edge between old and new in Shanghai. Urban Design International, 14(2), 65-83. https://doi.org/10.1057/udi.2008.9

\section{Published in:}

Urban Design International

\section{Citing this paper}

Please note that where the full-text provided on Manchester Research Explorer is the Author Accepted Manuscript or Proof version this may differ from the final Published version. If citing, it is advised that you check and use the publisher's definitive version.

\section{General rights}

Copyright and moral rights for the publications made accessible in the Research Explorer are retained by the authors and/or other copyright owners and it is a condition of accessing publications that users recognise and abide by the legal requirements associated with these rights.

\section{Takedown policy}

If you believe that this document breaches copyright please refer to the University of Manchester's Takedown Procedures [http://man.ac.uk/04Y6Bo] or contact uml.scholarlycommunications@manchester.ac.uk providing relevant details, so we can investigate your claim.

\section{OPEN ACCESS}




\title{
Original Article Blurring the joint line? Urban life on the edge between old and new in Shanghai
}

\author{
Deljana Iossifova
}

\author{
Department of Social Engineering, Tokyo Institute of Technology, 2-12-1 Ookayama, Meggro-KM, \\ Tokyo 152-8552, Japan. \\ E-mail: iossifova@web.de
}

\begin{abstract}
Urban renewal continues to play a major role in shaping the contemporary Chinese city. Old and run-down neighbourhoods either disappear to give way for new developments, or maintain their existence in immediate proximity to the latter. This small-scale ethnographic study, undertaken during 6 weeks on site in March and April 2007, examines the particular condition of spatial collision between the poor and the rich, the old and the new, the past and the future. It looks at an area of adjacent neighbourhoods in Shanghai, with focus on one recently redeveloped neighbourhood and one awaiting demolition prior to redevelopment. Their distinct spatial layouts and the lifestyles typical for their residents are found to join in a collage-like manner, thus forming an urban space of diversity and fragmentation. The very joint lines between those complementary neighbourhoods appear as rather dynamic entities, subject to continuous alteration in spite of their commonalities with static barriers. The paper proposes that collision between contrasting socio-spatial settings is - and will most likely remain - archetypical for the emerging Chinese city, as the poor, the old and the past are integral parts of the whole rather than diseases in need of eradication.

URBAN DESIGN International (2009) 14, 65-83. doi:10.1057/udi.2008.9
\end{abstract}

Keywords: Shanghai; urban renewal; urban boundaries; bordering; shared space

\section{Introduction}

A house may be large or small, as long as the surrounding houses are equally small it satisfies all social demands for a dwelling. But let a palace arise besides the little house and it shrinks from a house to a hut. (Marx and Engels, 1968, p. 83)

We are the time we live in. [...] We live in the three moments of expectation, attention, and memory, and none of them can exist without the others. You can't stretch toward the future because you've lost your past.

(Eco, 2006, p. 29)

During the socialist era in China, emphasis on urban zoning, proximity between the work place and the home, promotion of public transport, equal distribution of job opportunities, and equal living standards (for all) have been the guiding principles for city planning. Even as the city was divided into functional zones, people of different class and income shared urban space. In general, spatial segregation did not take place. Four main types of urban neighbourhoods (apart from newbuilt, inner-city commodity housing compounds) can be distinguished within the contemporary Chinese city: traditional neighbourhoods developed prior to 1949; work-unit compounds from the pre-reform era; satellite towns and mixed-use suburban communities consequential to urbanization during the past 30 years; and - surfacing during this same period - suburban villages $(\mathrm{Wu}$, 2001). The ongoing transition from planned to market economy has both helped to establish a new socio-economic structure and resulted in visible effects on spatial configuration. Communities and neighbourhoods are tending to be increasingly premised upon income and status (Wang, 2005). Now, pre-1949 spatial division seems to be magnified again due to housing commodification and socioeconomic differentiation, with effects such as inner city renewal 
generating up-scale residential developments on the one hand, and resettlement housing at the urban fringes on the other $(\mathrm{Wu}, 2002)$. With the ongoing displacement of formerly residential use by business and service functions (Gaubatz, 1999), original inhabitants of the Chinese city are dispersed and replaced. Recent examples include the project of the Maglev extension, broadly discussed in the international press (People's Daily Online, 2007a, 9 May; Spiegel Online, 2007, 13 March), or the displacement of several thousand residents in view of the upcoming EXPO 2010 (People's Daily Online, 9 November 2004 and 11 April 2005). In ambitiously aiming towards both building a 'harmonious society' and achieving the status of a global city, among many others the city of Shanghai has seen intensive urban renewal, 'cleansing' itself from the old and the poor through countless projects of gentrification - within the Chinese context referring to the displacement of original residents by new wealthier buyers of commercial housing through redevelopment in central areas' $(\mathrm{Wu}, 1998, \mathrm{p}$. 276). The displacement of urban dwellers into suburban (semi-rural) lands and the influx of rural migrants into the city create massive migrational forces in two opposite directions. Yet changes within the socio-spatial urban fabric are best perceived at the scale of the neighbourhood. In this paper, I will focus merely on capturing 'what happens between two periods, within the break or fold' (Lefebvre, 2003, p. 28) capturing the fleeting status quo of one exemplary Shanghainese location in transition.

\section{On Bordering}

Within the context of urban renewal in the Chinese city, in the course of creating new urban realities, redevelopment projects seem to reproduce specific patterns of spatial (and social) bordering (Figure 1).

1. After selection of a site for renewal, a demarcation line is carefully drawn to define the boundary of the future development, often running through existing neighbourhoods, and arbitrarily dividing them. Residents of the area thus demarcated are informed of the projected undertaking and over time removed from the site. Reimbursement for their loss is by means of either monetary compensation or a new home in most cases located on the urban fringes and thus far away from the original location.
2. The process of site clearance can sometimes take up to several years, allowing for the remaining building substance (now emptied of original inhabitants) to be occupied by a temporary population until its final demolition. In many instances, rural migrants new to the city make use of still habitable buildings, often as their only available option for housing, and regardless of the usually decaying surroundings. When existing buildings are finally being demolished and reusable materials carted off, residents of adjacent communities often feel alarmed by the events in their immediate proximity, but are frequently (depending on the level of transparency) forced to remain in a state of uncertainty regarding the future of their own neighbourhoods and homes.

3. A temporary fence along the perimeter of the previously demarcated and flattened construction site disconnects it from its environment during the following stage of construction. Once again, temporary residents occupy the hence distinguished space: construction workers, in most cases migrant rural workers, frequently accompanied by their wives and children, reside in temporary dormitory buildings provided by their employer for the duration of their assignment.

4. Upon completion of the redevelopment project, the construction workers and their homes are removed (and relocated to a new work site) - as is the temporary fence along the perimeter. In its place often appears a new and permanent fence (or wall), only interrupted by a few securitycontrolled gates. Promising safety and exclusivity, the new development is now ready to receive its future residents and users, the individuals it was designed and built for. At this stage, contrasting spatial concepts, architectural styles, building techniques and - most importantly - contrasting people and their respective lifestyles collide in space and time (only separated by a fence or wall), to reveal the past and the future within a transient present.

5. The coexistence of diverse identities and lifestyles is often limited to only a short period of time. Gentrification takes over and redevelopment projects spread out to conquer their surroundings, destined to eliminate remainders (and reminders) of the poor, the old, and the past, and replace them with the homogeneous structure of what is considered the 'modern' and most profitable for the parties in power involved. 
spatial evolution

1)

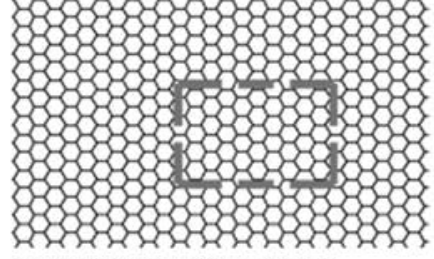

demarcation of site for renewal, temporal fencing

2)

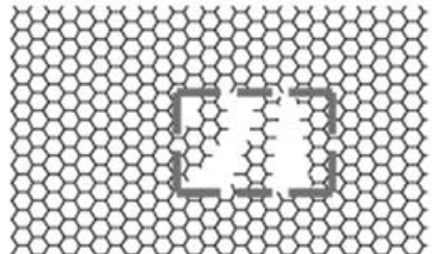

demolition of existing built environment

3)

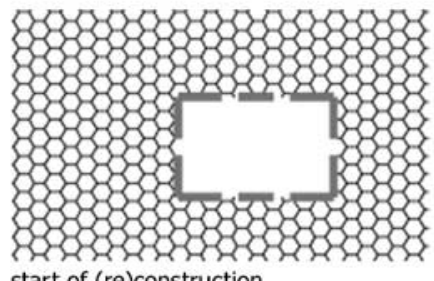

4)

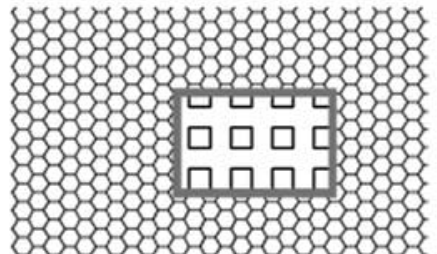

completion of new development, permanent fencing

5)

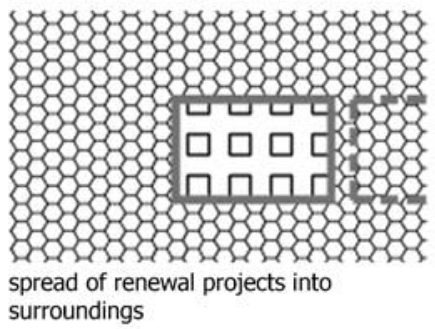

occupational evolution

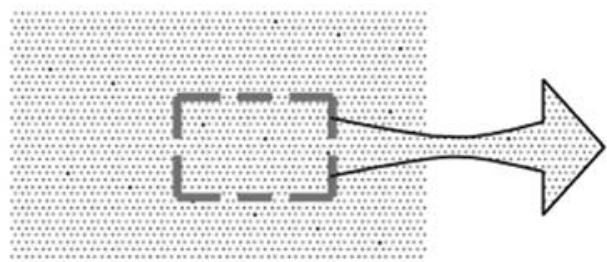

displacement of original inhabitants/ users

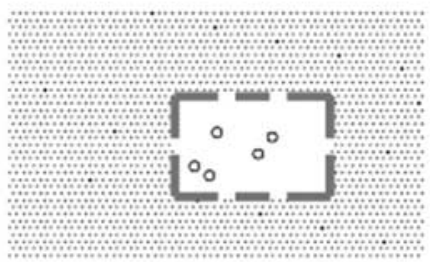

temporary occupation by floating population, homeless, poor

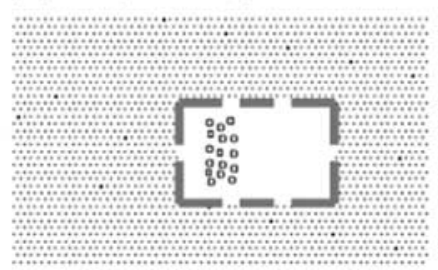

temporary occupation by migrant construction site workers

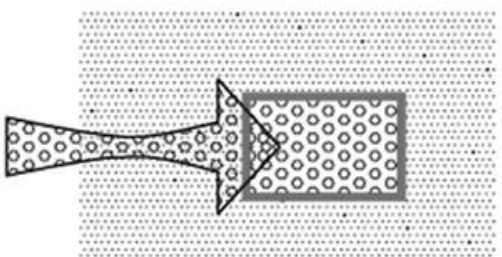

influx of new residents/users

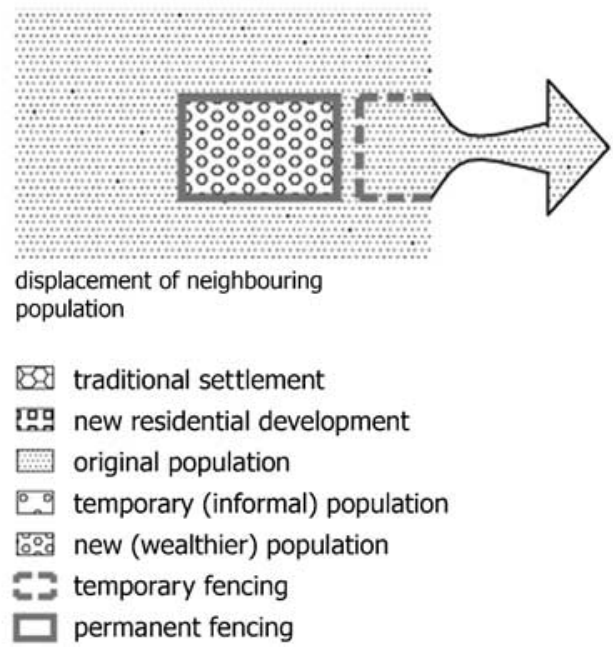

Figure 1: Bordering and the process of inner city renewal. 
This conceptual outline demonstrates how while transformations of spatial and social impact take place - boundaries enclose space and the human actors within them. Notably, many of the actors involved in the theatre of urban renewal (and in turn party to its effects) are rural migrants, both new to the city and resident there for many years, or even generations. Back in the pre-1949 era, for rural migrants 'to go to Shanghai was something quite like immigrants entering the United States to pursue their "American Dream"” (Lu, 1995, p. 565). Still (or even more) today, internal migration in China shows a resemblance to developing-to-developed-countries migration (Roberts, 1997). As migration in itself refers to boundaries, boundaries themselves change their purpose and quality over time. They 'are not static; neither are they permanent structures. As human constructs they are historically contingent processes, which emerge, exist for some time and disappear' (Newman and Paasi, 1998, p. 201).

Political geography differentiates between the 'antecedent boundary' - a boundary created prior to the establishment of a region and thus a 'catalyst for the formation of separate cultural and socio-spatial entities', and the 'subsequent boundary' - a boundary 'superimposed upon existing patterns of human settlements' (Newman and Paasi, 1998, p. 190). How boundaries are demarcated is important, as it indicates how they are managed, what level of permeability they possess and to what degree they are institutionalized. Demarcation as such implies both the existence of difference that initiated the border and the differences enclosed by the border (with the term 'border' usually denoting a barrier of protection against outside influences). Determination of who is included or excluded is considered a significant part of boundary demarcation (Newman, 2003). Boundaries therefore represent the social practice of spatial differentiation, especially evident when society is confronted with socially 'dirtified' people - 'heimatlose', asylum seekers and the like in the international context (van Houtum and van Naerssen, 2002, p. 129) - the poor and the homeless on the scale of the city or neighbourhood. In their attempt to 'purify space', those in power frequently exclude the unwanted, or 'other' (Sibley, 1995). Since territory is understood as one dimension of identity, the construction of socio-spatial identities is therefore clearly connected to the construction of borders (Newman, 2003). Exploring the role borders play in the formation and development of socio-spatial identities appears crucial when attempting to capture the status quo of the fragmented Chinese city. Drawing on first-hand observations on site, in the following chapter I will explore life on the joint line (or 'borderland') between dilapidated dwellings from the pre-communist era and brand-new high-rise residential developments in Shanghai.

\section{Approaching the Study Site}

After careful consideration of several options, I selected the study site (Figure 2) owing to the patchwork of contrasting socio-spatial entities prevalent. The site comprises, among a number of other varieties, one 'traditional' neighbourhood and one recently completed residential compound featuring urban high-rise housing. Although several different kinds of borders demarcate the respective neighbourhoods, a street most effectively separating the old and seamy parts in the west from the brand-new parts in the east serves as a clearly defined borderline. In addition, the site location is in direct proximity to the Suzhou Creek, a historical line of division between divergent parts of the city in earlier times.

Suzhou Creek flows through the city of Shanghai and into the Huangpu River. It has historically divided the city into the southern part of international settlements and the northern part of Chinese jurisdiction, both of which chose to turn

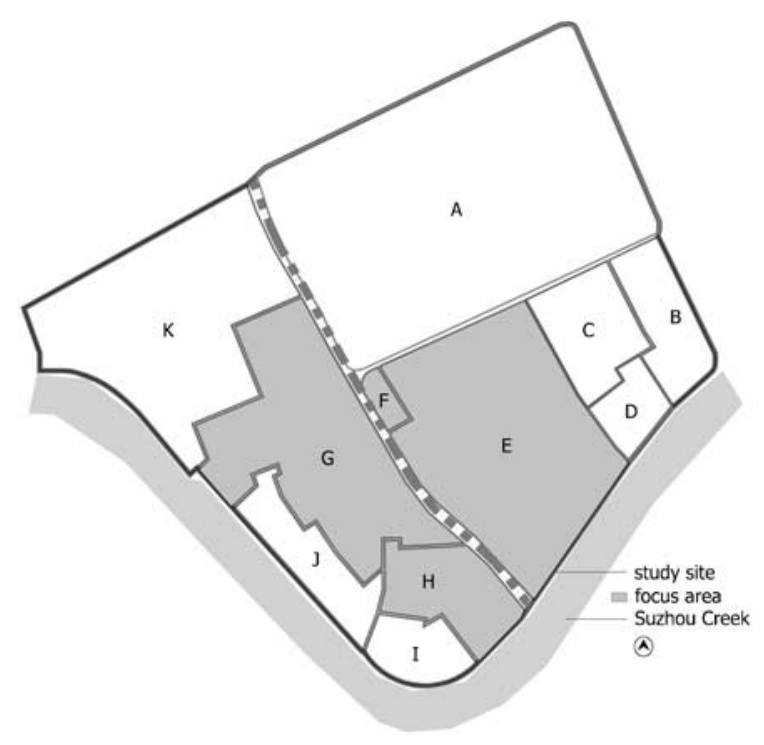

Figure 2: The study site. 
their backs on the Creek, known for its negative qualities on account of the many polluting factories and warehouses occupying its banks. Particularly the northern bank emerged as a breeding ground for slums during the first half of the twentieth century by attracting rural migrants and the poor ( $\mathrm{Lu}, 1995)$; a legacy that has caused much concern during later phases of the city's development. Just 10 years ago the government decided on a renewal campaign for the Creek, which 'includes the preservation of historic buildings, the reorganization of the traffic system, the creation of parks, the establishment of water platforms and the reconstruction of the riverbank' (Marshall, 2004, p. 164). Ever since, the government has been searching for suitable (and sustainable) solutions aiming to improve the urban conditions along the Creek and to connect the two parts of the city better; currently, bridges spanning over the Creek are being widened in order to accommodate an ever growing amount of automobile traffic (Shanghai Daily Online, 10 April 2007). The master planning for the Creek's redevelopment was assigned to the well-known international design firm EDAW, who claims that the master plan has been generated as a reaction to the existing context and the projects already approved and under construction. EDAW promises a development framework featuring 'a diversity of project types' and 'a compatibility of scales and textures [...] through urban design guidelines' (Marshall, 2004, p. 165). The riverbank renewal campaign launched by the municipal government also directly affects the study site, situated on the north bank of the Suzhou Creek. It is located roughly $7 \mathrm{~km}$ from Shanghai's city centre and within Putou $\mathrm{Qu}$, one of the city's 10 central districts, and among them the one with the highest percentage (19.9 per cent in the year 2000) of migrant workers (SFPCO, 2002). As a whole, the study site covers 33.5 ha, out of which a focus area of approximately 14.5 ha has been examined in greater detail (parts E, F, G and H in Figure 2).

The research strongly relies on a range of visual methods (Bangert et al, 2002), and providing only a brief explanation of the strategies applied in the following chapter, I will elaborate on analysis and results in a separate paper.

As a first approach to defining the perimeter of the study site, a map was used to draw a preliminary boundary based on the features of the site discernible - for example, the Creek or an inner-city highway (Figure 3). Following the first site visit, the boundary line was redefined in response to the actual conditions on site (for example, seemingly insurmountable barriers or unexpectedly accessible paths). With this newly emerging boundary line as a guide, a series of images was recorded in order to capture the path itself and the changing conditions of the surroundings. These ranged from narrow lanes lined by shanty housing to spacious sidewalks between six-lane motorways and mixed-use high-rises.

With the intention to create a catalogue of spatial features (internal building structures, open spaces and atmospheres), a second series of images (Figure 4) was recorded based on a grid of nodes previously superimposed on the site map (random grid size $26 \mathrm{~m} \times 31 \mathrm{~m}$, Figure 5). One photograph was taken at each node of the grid, wherever feasible, in the direction of Suzhou Creek. The four differing parts chosen as the focus area (Figure 2 - parts G, H, F and E) crystallized in this way.

Part G shows the character of a 'slum', where obviously little more than 'additions and insertions' has been done in order to maintain the building substance within the past 60 years (Wang, 2005, p. 67). Part G emerged from one of the many historical shantytowns of the pre-1949 era along Shanghai's Suzhou Creek (Lu, 1995). As the area was poor even before the socialist era, current conditions on site seem to validate the finding that one major cause of 'areas of urban poverty' is their 'historical legacy' (Wang, 2005, p. 87). Part G is made up of low-rise, mostly twostoried, run-down buildings, arranged along narrow alleys (1.5-2.5 m wide) with only scarce incorporation of open space (see Figure 6, depicting the amount of open space for the adjacent neighbourhoods - just one of many contrasts). Common building materials for this area include wood, concrete, masonry (hardly ever plastered), plastic planes and corrugated steel. Windows and air-con units are often broken. Space inside the purpose-built structures appears in significantly short supply given the overcrowded situation; hence, over time residents have added expansions in form of small rooms and even multi-storied structures, taking up considerable parts of the already quite narrow alleys. These accommodate water sinks, cooking and storage facilities, tables, chairs, televisions and computers, workbenches, bicycles and other means of transportation, and countless numbers of chamber pots. As most homes lack bathrooms, residents are bound to share the nearby public toilet. They sleep, cook, do and hang the laundry, wash their hair and 

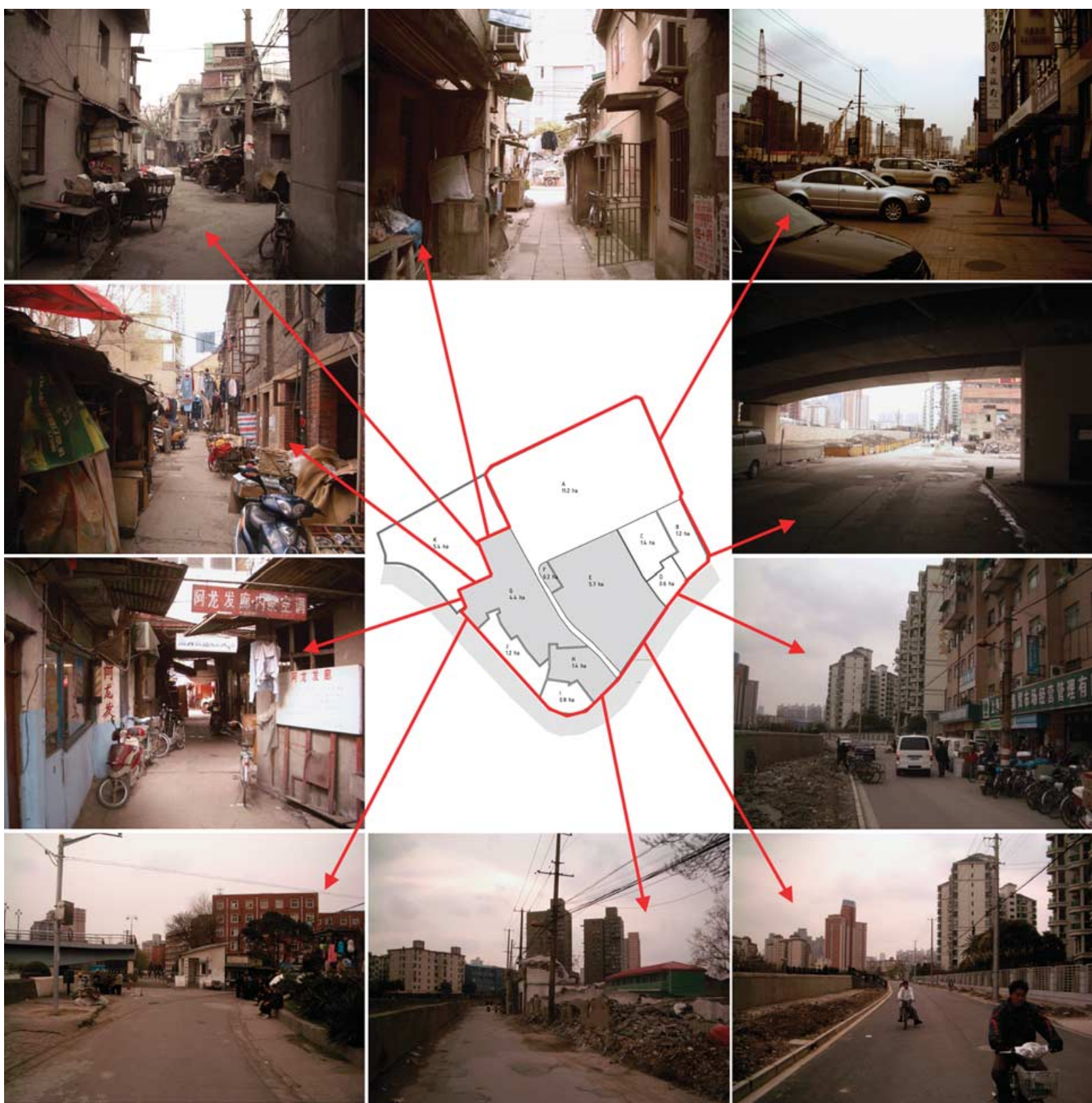

Figure 3: Exterior limits of the study area (excerpt from series of images).

brush their teeth in the alleys. At mealtimes, they have the doors to their homes open and communicate with neighbours or even eat outside in the alleys altogether. They gather in front of their entrances for chats, while vendors sell goods, children play, and free-range chicken and other 'farm' animals run around freely. Strikingly, compassionately maintained plants in pots of all sizes stand about lining the alleys, gracing entrances to homes, hiding shabby balconies and roofs from unauthorized views, and making for islands of beauty before the background of their run-down environs.

Before the riverbank redevelopment campaign took its toll, part $\mathrm{H}$ of the study side used to accommodate industrial facilities and housing units. These were demolished to make place for a recently completed, rather poorly received public park with small artificial hills and shady trees. Sparse visitors fly kites, hang laundry out to dry or take a rest, yet more commonly, people use the green area as a car park. A temporary, 


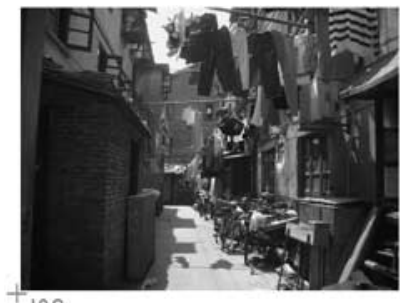

d08

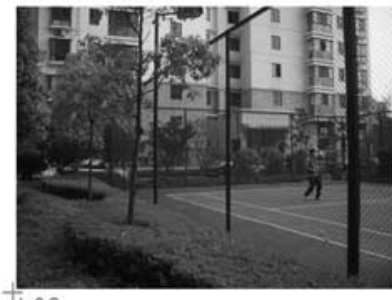

k08

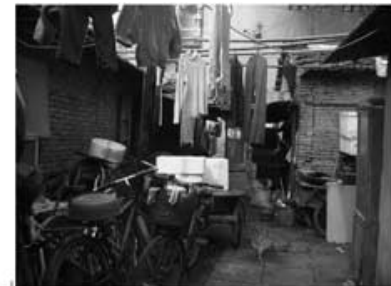

f07

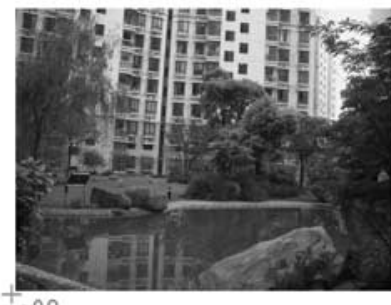

008

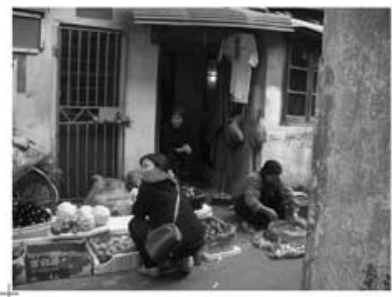

hos

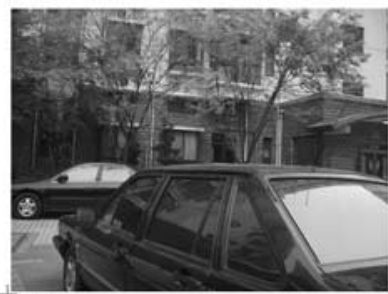

$\Gamma 10$

Figure 4: Catalogue of features (excerpt from series of images).

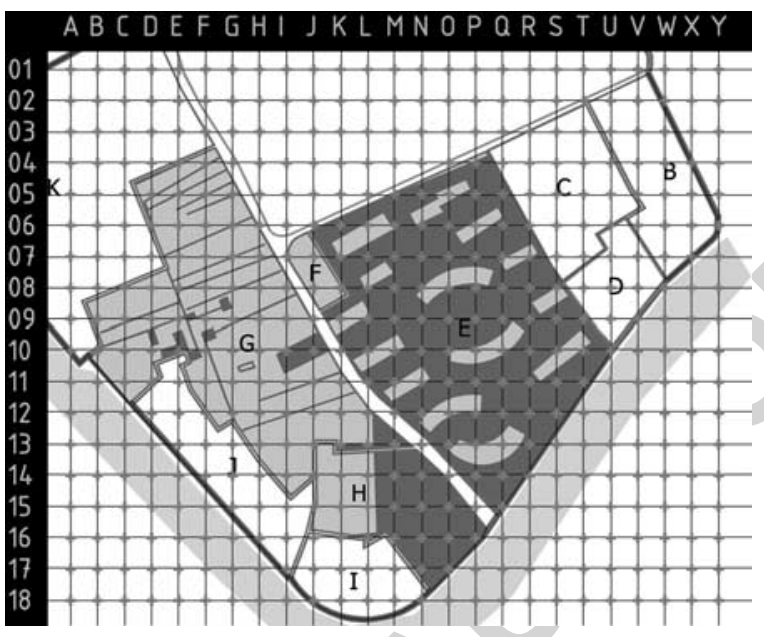

Figure 5: Random grid base for visual cataloguing. Wherever possible, one photograph has been recorded facing the river at each node of the grid.

two-storied migrant worker dormitory, surrounded by a $2 \mathrm{~m}$ high masonry wall, occupies the northern part of the area.

Part F of the study site consists of a six-storied residential building, which houses Shanghai Gas Corporation employees. A huge bicycle park space is located in the back of the building, while the ground floor facing the street (the 'joint line') accommodates shops, restaurants and services. The shops and eateries spill out onto the sidewalk, offering outdoor seating, billiard tables and similar entertainment utilities excessively frequented by residents and passengers during most hours of the day.

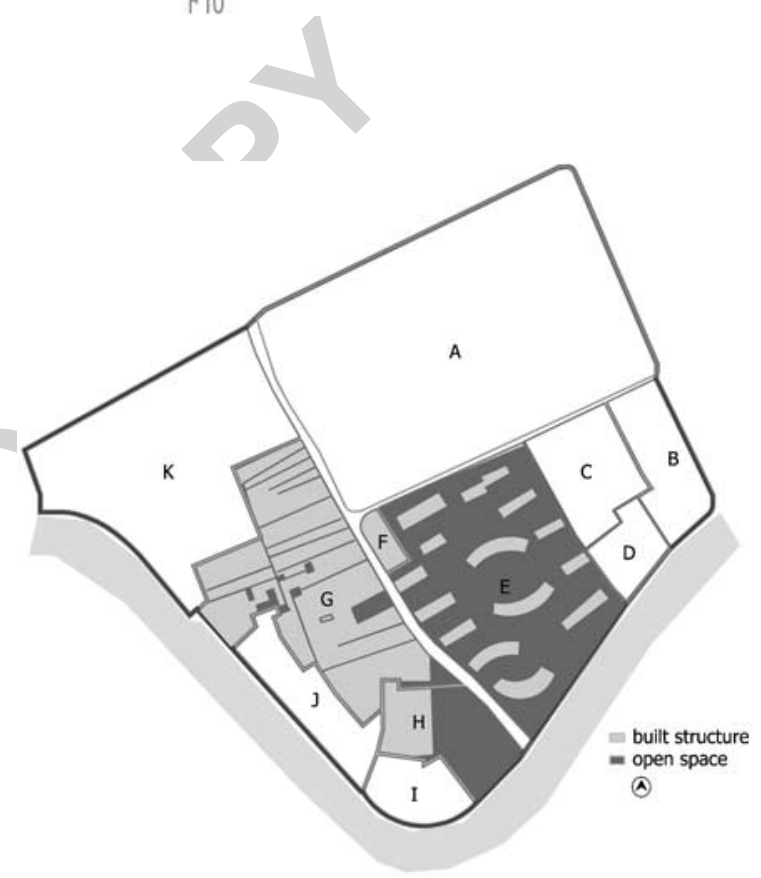

Figure 6: Just one dimension of contrast: open space vs build space.

Part E of the study site accommodates a modern residential high-rise compound. When completed in 2002, the compound replaced industrial facilities. A fence surrounds it, open to the (authorized) public at two guarded points. One of the gates is located in the south adjacent to part D, another in the west opposite part G. A service gate can be found facing part $\mathrm{A}$ in the north. The compound is composed of more than 10 high-rise buildings with $15-18$ stories each, some of them slightly curved to create pseudocourtyards featuring tennis-courts, exotic landscapes and even a small park with artificial lakes 
and creeks for the residents' enjoyment (paradoxically, the park itself is fenced against the compound and only accessible through an internal gate). Yet the internal green space is rarely utilized. Only few residents, mostly the elderly and mothers with children, occasionally gather to sit together and chat; more often, it is the 'outsiders', who come in to enjoy the greenery. In fact, most people I encountered during site visits inside the compound's perimeter were employees, be it guards or gardeners. A clubhouse, which takes up the ground floor of one of the central high-rises, completes the compound's communitarian facilities: it offers little more than a large empty space and huge posters hanging from the ceiling, reminding residents of the management company's efforts to work together with them as to create a 'human district'. Almost any point within the compound is accessible by car, and a large underground parking garage connecting directly to the individual high-rises is located underneath the artificial landscape. Nonetheless, bicycles often line the pathways close to the buildings' entries.

As developers are working towards appropriation of parts C, B and D of the study site in order to create a consistent up-scale residential compound, the previously discussed patterns of renewal, bordering and expansion (Figure 1) can be observed at work. Part B (characterized by a small factory, a small area of Shanghai-typical 'lilong' housing, and some individual homes) has been almost completely demolished and its original residents almost completely displaced to locations in Shanghai's satellite towns. A few residents, however, remain within their homes, continue their daily routines and await their final relocation. From windows and balconies previously overlooking vivacious alleys and green courtyards, they now look onto plots of debris and piles of garbage (Figure 7).

In short, within the perimeter of the study site subsist areas representing three different stages in urban development (and the peculiarities of their coexistence): traditional and dilapidated housing; housing undergoing demolition in view of redevelopment (a temporal borderland as opposed to the spatial borderlands yet to be discussed); and modern high-rise housing.

\section{Exploring the Joint Line}

After compiling a catalogue of spatial features, a third series of images was recorded (Figure 8), focusing on the space between parts $\mathrm{G} / \mathrm{H}$ and $\mathrm{E} / \mathrm{F}$ - the joint line. Capturing both sides of the street at intervals of approximately 20 steps, these photographs help to specify and compare the characteristics of the border space, the adjacent neighbourhoods and their respective users.

For example, the sidewalk on the west (old) side (parts $\mathrm{G} / \mathrm{H}$ ) is mostly lined by makeshift structures open towards the street, accommodating shops, service booths, small eateries and housing. On average, the structures here are temporary, added within recent years and made of cheap materials. Commonly observable is the typology of the 'garage shop', a space of about $10 \mathrm{~m}^{2}$, simultaneously used by its inhabitants for living (when the roller shutter separating it from the street is down) and business (when the shutter is up and the shop expands to take up the entire sidewalk). The sidewalk, if at all walkable, appears narrow and crowded on the west side, while on the east (new) side (parts E/F) it is very spacious, characterized by a monotonous seethrough fence along the perimeter of the new residential compounds. Trees on the west side are in general large and old, and often seem to grow out of the makeshift structures erected around their trunks, whereas on the east side even the small and young trees are only recent additions. Residents of G/H and their belongings 'conquer' the roomy sidewalk across the street, typically
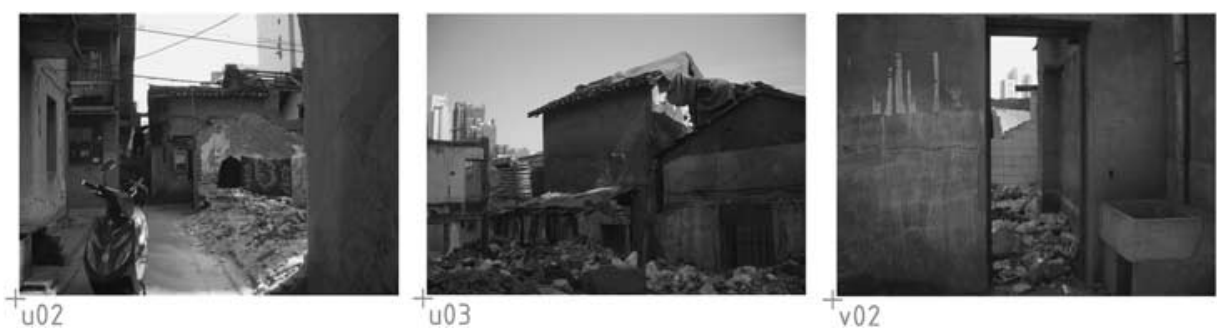

Figure 7: Catalogue of features, part D. 

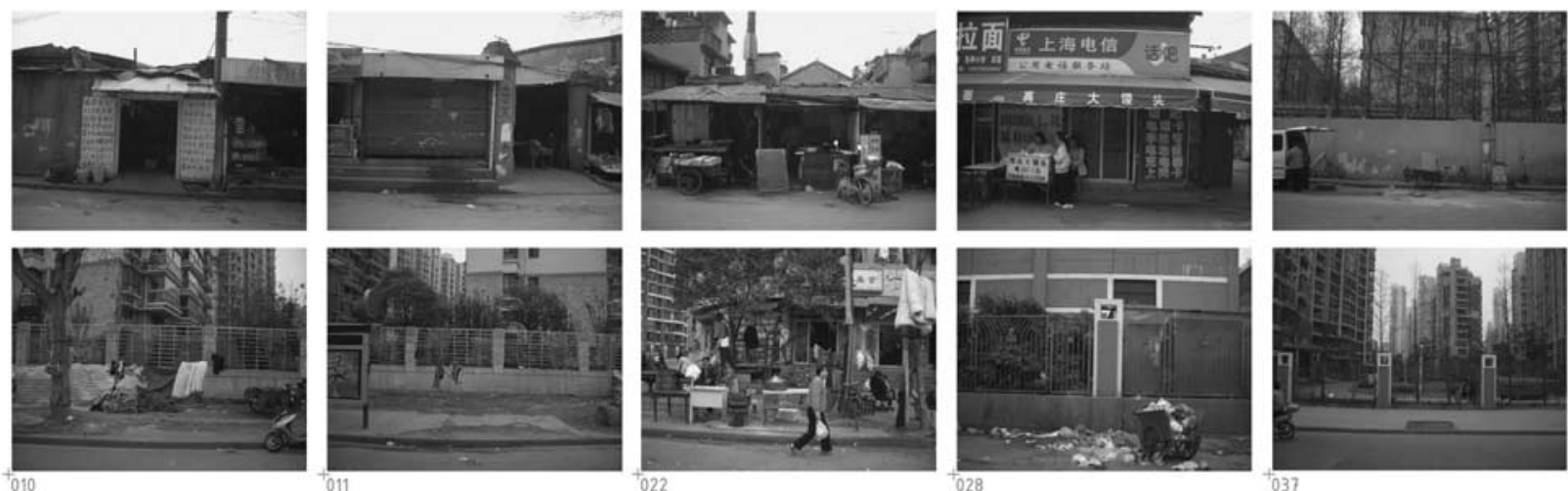

Figure 8: The joint line. Two sides of the same street (excerpt from series of images).

using it to hang laundry to dry (either directly attaching their laundry to the compound's fence, or using clotheslines that span between sparse trees and the fence). Dumping garbage along the fence is another common habit - despite of the public garbage collection point located nearby. In the daytime, the new sidewalk often accommodates extended facilities - such as living room furniture brought outside to create an outdoor living room 'in' which (part G) neighbours meet and play mah-jongg (Figure 9). During the night, it mainly serves as storage space, for example for piled up building materials, protected from the weather by simple plastic planes. It also serves as a place to park the wheelbarrows and velocipedes of (part G) residents and flying vendors. All sorts of nomad service providers set up their stands along both sides of the street - choosing their preferred side depending on the weather. Noteworthy, although a public toilet is located on the west side, male locals and passers-by (including both pedestrians and drivers, most often taxi drivers) prefer to simply use the fence on the east side as a toilet - which explains the emblematic smell perceivable along the street. Correspondingly, I occasionally encountered children who, without causing much of a stir, were defecating on the sidewalk along the west side. People were using this same sidewalk at other times for washing themselves and the children, preparing food or for other unrelated activities. Washing cars is another commonly observable activity along both sides of the street, whereat passersby and residents of part $\mathrm{E}$ hand their limousines over to one of the several quickly set-up car wash stands (mostly operated by residents of part G), and pick them up vacuum-cleaned and shiny a few minutes later.

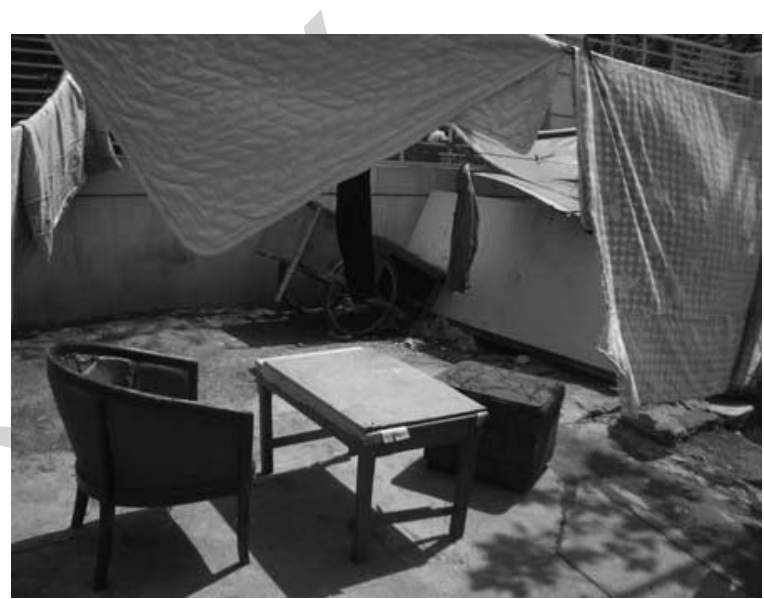

Figure 9: Sidewalk turned into living room.

The streetscape (joint line) joining the old neighbourhood with the new appears to be acting

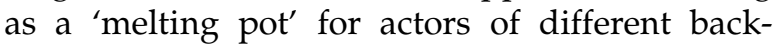
grounds, who temporarily appropriate space and assign to it specific uses in order to fit their momentary and differing needs. More broadly spoken, public space is temporarily privatized (for example, sidewalk-turned-living-room), and private space in turn is temporarily made public (for example, living-room-turned- shop-space).

A fourth series of images (Figure 10), recorded every $10 \mathrm{~min}$, and videos, recorded once per hour and of the duration of $1 \mathrm{~min}$ each, resulted from the endeavour to capture potential patterns of day-to-day life on the joint line by covering all 24 hours of the day. The photographs were taken during one week in early April 2007, and the position of the 'observation post' allowed for surveillance of several key features on site (Figure 11), such as: the western entry gate into 

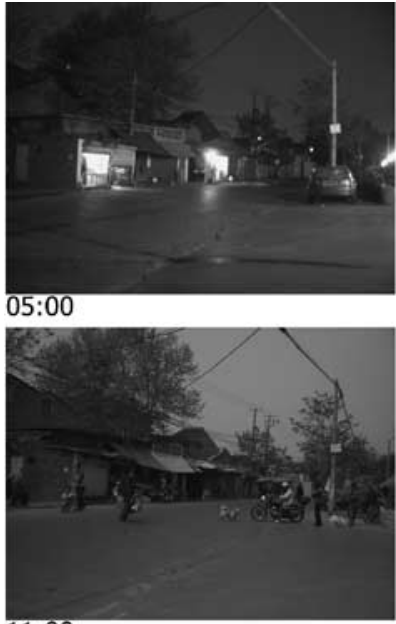

11:00

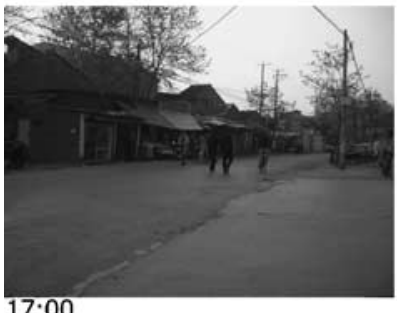

17:00

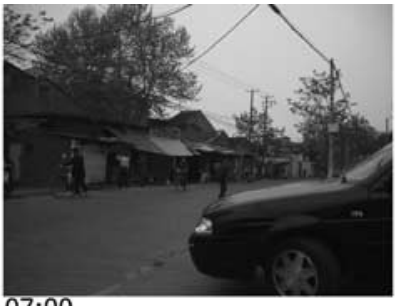

07:00

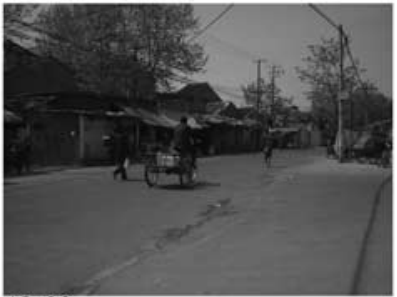

13:00

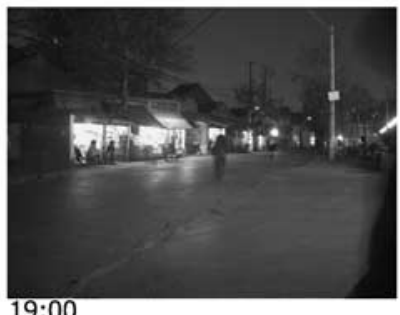

19:00

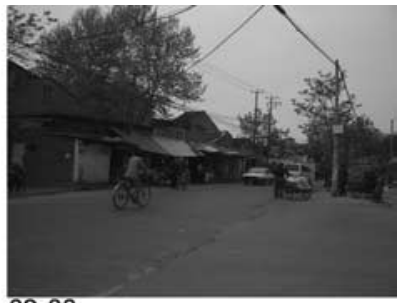

09:00

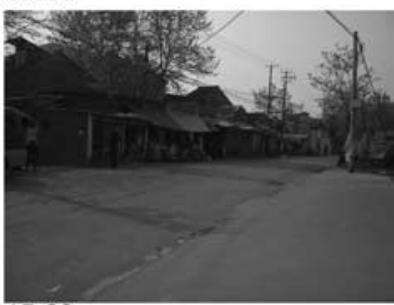

$15: 00$

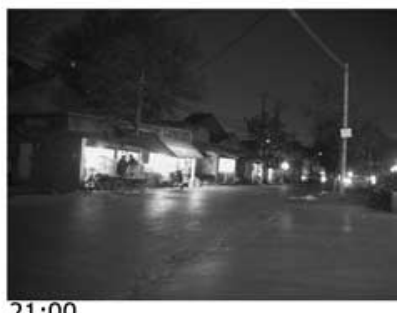

Figure 10: Twenty-four hours (excerpt from series of images). The photographs have been selected from a series of images recorded on various days during the first week of April 2007.

the new residential compound (E); numerous alleys leading into the old neighbourhood (G); the entrance to the large wet market (an indoor market selling live animals and fresh groceries, ca. $800 \mathrm{~m}^{2}-\mathrm{G}$ ); the public toilet serving the old neighbourhood $(G)$; the eateries, shops and homes (along G) vs the see-through fence (along E) lining the street between the two parts - the joint line.

The joint line appears bustling with people and vehicles, from early in the morning throughout the day and until 2100 hours, when 'garage shop'shutters shut down and most businesses dilatorily close for the day. Generally, life in part G starts as early as 0500 hours, and part E awakens slightly later, at around 0630 hours Correspondingly, the lights in part $G$ commonly are turned off at about 2200 hours, and part E stays awake until midnight.

The reoccurrence of several ordinary events surfaced as worthwhile recording during observation of life on the borderland and my attempt to draw a pertinent image of the place: police cars and taxis passing by; 'big black cars' (significantly outnumbering other types of limousines) pulling into the new compound (E); vendors riding velocipedes and ringing bells to attract attention

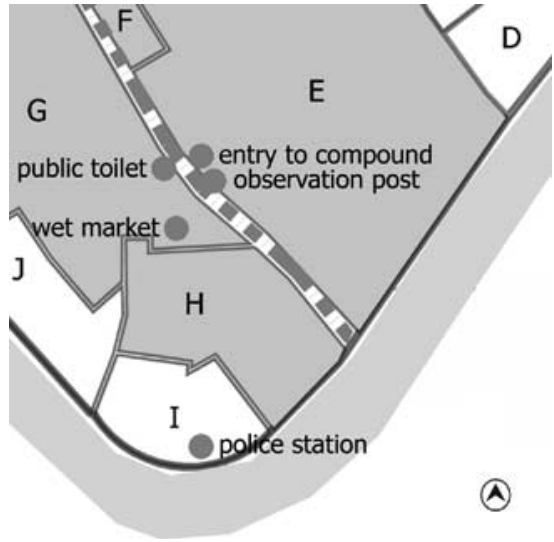

Figure 11: Key features on site.

and collect/sell used goods; residents of area E crossing the street (joint line) to buy groceries at the wet market; or make use of any other service offered by representatives of area G (Figure 12).

For example, police cars (attributable to the police station located in the south of area I) start to appear as early as 0500 hours, reach a maximum around 1400 hours with up to 15 police cars passing per hour, and thereafter their number 


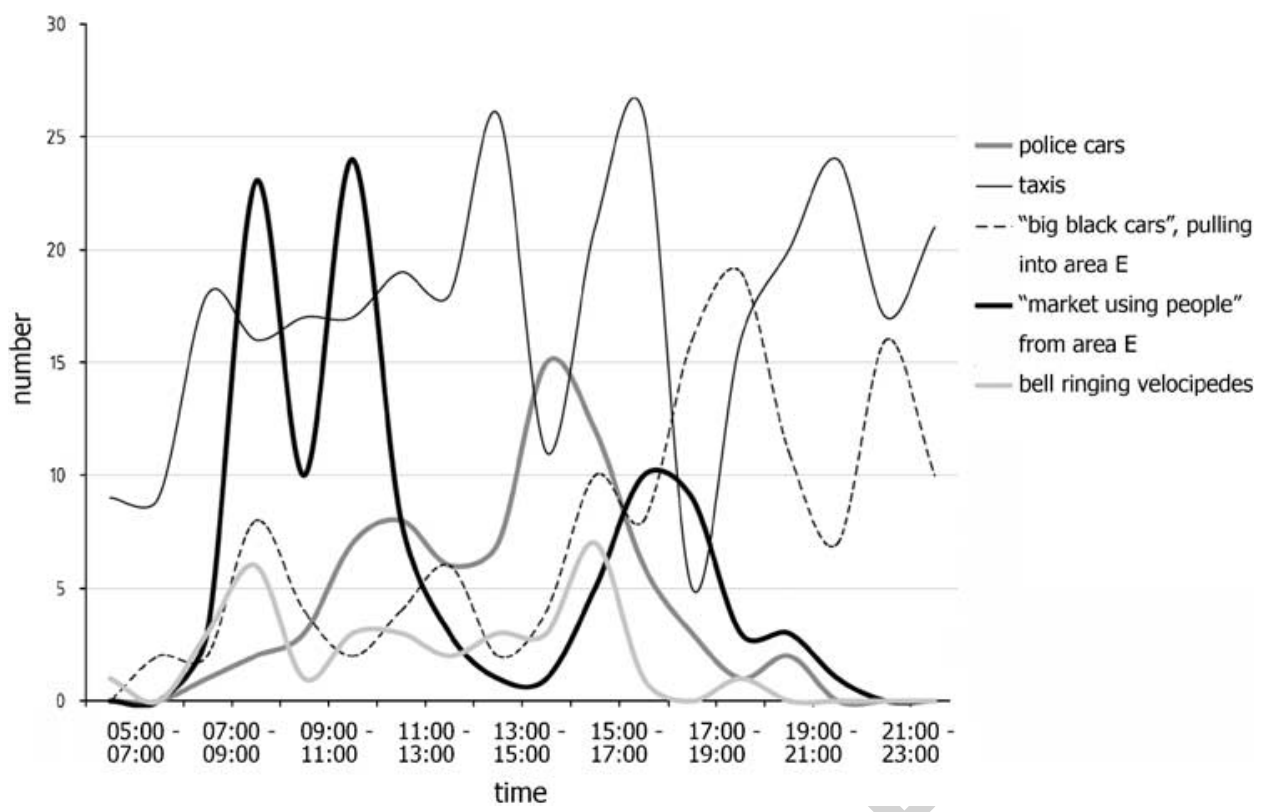

Figure 12: Twenty-four hours, statistical diagram.

decreases to insignificancy at around 2000 hours in the evening. The number of taxis passing by, dropping off or picking up passengers peaks between 1300 hours and 1400 hours and again between 1600 hours and 1700 hours with up to 26 taxis per hour. Their frequency decreases to a low of five taxis per hour between 1700 hours and 1800 hours - empirically one of the busiest times in the city during the day, when it is almost impossible to find a taxi. In regards to "big black cars', I merely recorded those pulling into the compound, so their number is only representative for the residents returning to their homes or being dropped off. (Also, the numbers are only indicative to residents using the west gate of the compound, and the number of residents using the south gate is excluded.) Their number rises at around 0700 hours, goes up and down throughout the day, reaches a first peak of 19 cars per hour between 1800 hours and 1900 hours and another between 2100 hours and 2200 hours most likely ascribable to residents returning from work after 1800 hours and from dinner after 2100 hours The probably most important graph to this study in the diagram represents the number of 'market-using people from area $E^{\prime}$. The graph shows that residents of $\mathrm{E}$ use the market a lot, especially in the morning hours in preparation for cooking lunch, with peaks between 0800 hours and 0900 hours and between 1000 hours and 1100 hours, when numbers reach up to 24 shoppers per hour. Another small peak appears in the late afternoon between 1600 hours and 1700 hours, when residents are bracing themselves for dinner (which typically takes place around 1800 hours).

Besides revealing the existence of certain patterns when it comes to daily life on the borderland, the diagram supports the claim that interrelations between actors of different backgrounds exist, even if merely limited to the level of economic exchange. In the next section, I will explore in detail who the specific actors are and in what ways they interact.

\section{Actors of the Borderland}

During the many visits to the site, and especially to the borderland between the old and the new neighbourhood, I was able to distinguish several 'key players' (people, who were always present, or whose presence I considered important for understanding the socio-spatial interconnectedness on site - Figure 13).

For instance, from my 'observation post' at the west gate of the new compound, I was in the position to keep an eye on the day-to-day life of a family of three (mom, dad and their toddler) inhabiting 'shop 01' (a 'garage shop' - a room featuring only a shutter to separate it from the street) and selling everything from underwear to rubber valves. Next door and in a room of the 


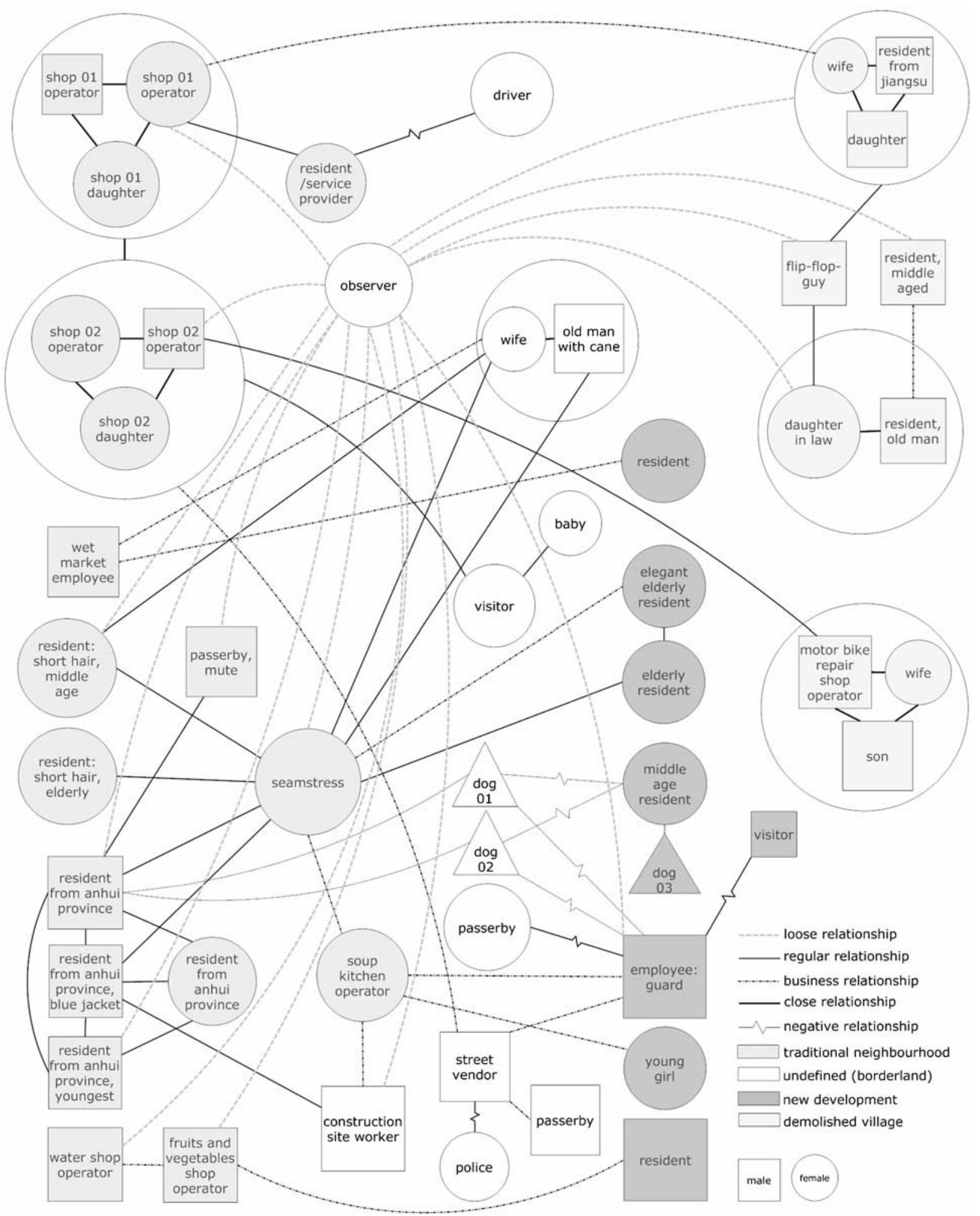

Figure 13: Ecomap: Actors and their interactions. 
same typology resided the family of 'shop 02 ' with their 3-year-old daughter, specializing in hardware. During brief conversations, family members of both families revealed that they are from Jiangsu Province, but have lived in Shanghai for several years, and maintain a close relationship among each other - frequently helping each other out with cooking or childcare.

In close proximity to the two shops and right next to the public toilet stands a ramshackle hut with nothing more than a curtain for an entrance, inhabited by several people (I was unable to determine their exact number during the entire duration of my presence on site) and simultaneously used as a warehouse for building materials. Some members of the 'Anhui-gang' (all of the individuals engaged in the business turned out to be from Anhui Province) were responsible for packaging, others took care of transportation and the only woman among them was responsible for bookkeeping. One of the middle-aged men in the team - the 'owner' of two dogs spending their days roaming the street, yet allowed into the shack over night - reported that he has lived in Shanghai for more than 5 years and really likes it (Figure 14).

The phenomenon of 'migrating networks' within the context of international migration (van Houtum and van Naerssen, 2002) appears here on the level of rural-to-urban migration in China. Entire networks of people from the same province (and often from the same village) transfer into a new setting, in this case the city of Shanghai, thus linking their new (or temporary) home with their old (or other) home.

Contrary to this group of long-term migrants, I could locate several instances of migrants who just recently moved to the city. Among them are of course the many construction workers and their families residing at the dormitory in part $\mathrm{H}$ of the site; but also, for example, a comparatively young couple - from Jiangsu Province - with their

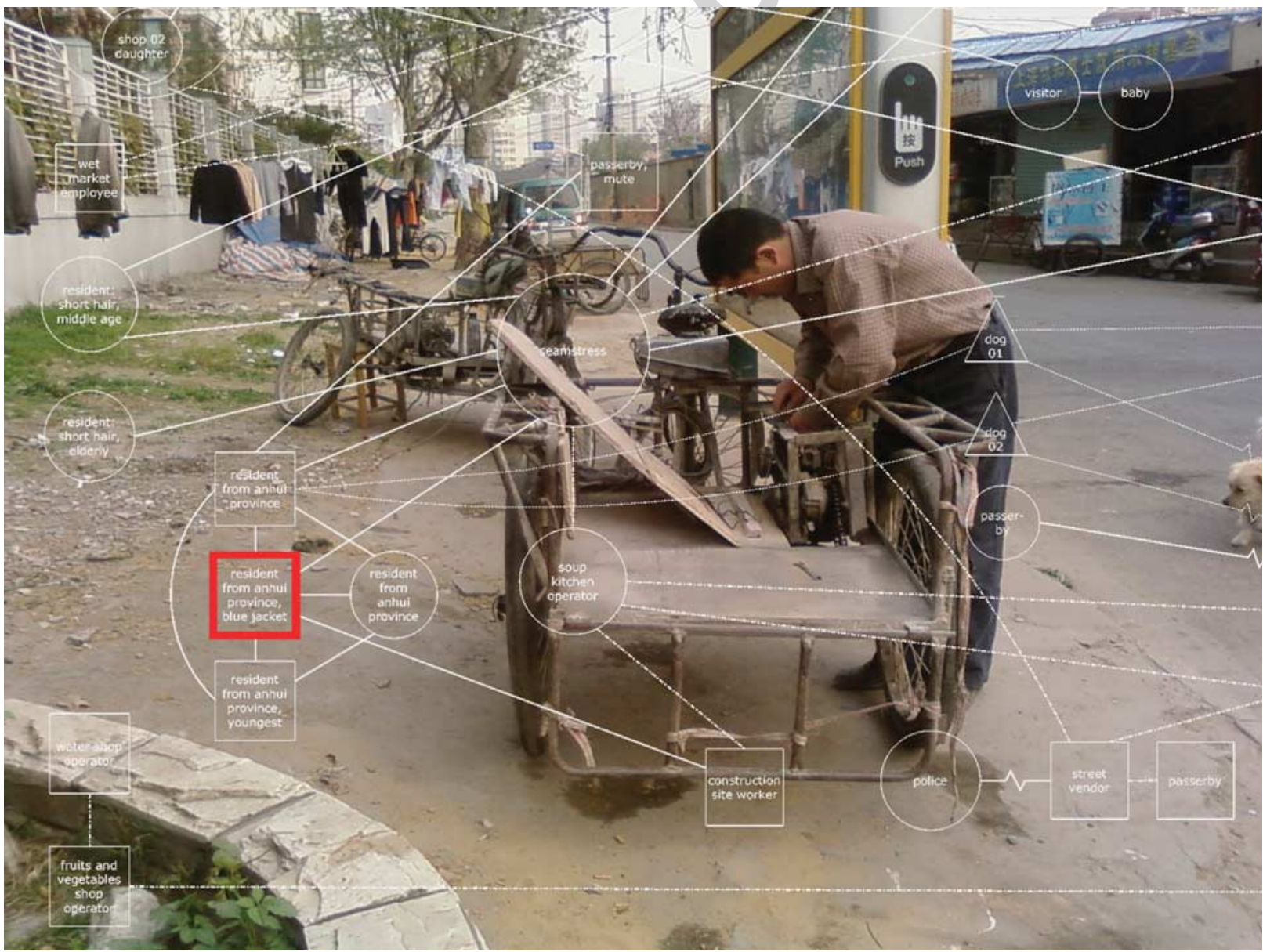

Figure 14: Living and working on the joint line: Self-employed migrant from Anhui province. 
toddler, inhabiting one very small, semi-demolished house situated in part B of the site. During short conversations, the young mother told me that their family (including her sister) came to Shanghai in search for work only 3 months ago. Apparently, as they cannot afford a 'real place', all of them and some 'friends' live in the small house. The situation significantly resembles the circumstances in Shanghai during the pre-socialist era: 'The urban outcasts of Shanghai were those people who were forced by desperate circumstances in their rural homes to flee to the city in search of sheer survival. Being mostly uneducated and unskilled labourers, they often could not compete with other, earlier urban-based migrants in the city. Failing to find stable employment, they squatted on whatever vacant area they could find in the city, where they erected "temporary" hovels as their homes' (Lu, 1995, p. 589). Even so, I could frequently see the young woman and her daughter walking the streets, talking to passers-by and visibly integrating within some sort of social network.

As mentioned earlier, a number of long-term residents awaiting their final relocation to new homes in the suburbs still inhabited part B of the site (some of them have reportedly lived there for over 50 years; Figure 15). Although many preferred to remain silent about their situation, several were willing to give detailed explanations and complained about the long commuting times from their future homes, or the disconnection from friends and relatives who would continue to live in the inner city. Regardless of their background, residents of part B seemed remarkably well connected. Regularly, people I saw or talked to for the first time already knew about my existence and my interest in the area.

Residents of part E remained anonymous to me for the most part, presumably because they often used either private cars or taxis for transportation, and thus frequently passed by without an

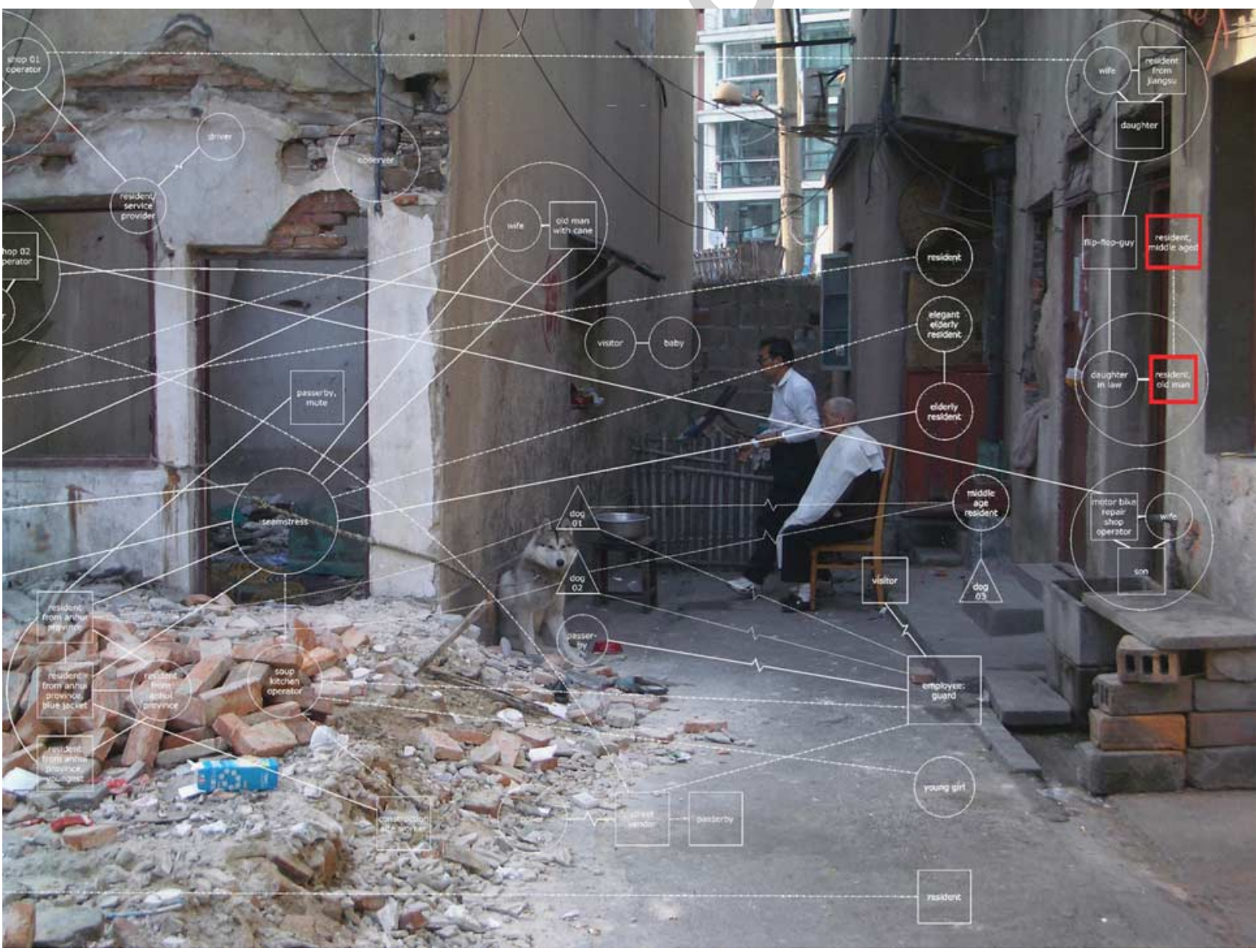

Figure 15: Living 'in-between': Residents awaiting their resettlement. 
opportunity for interaction. Inside the compound, most of the people I encountered were employees going after their duties. I attribute the absence of evident community life within the places designed to facilitate it (be it the small park inside the compound or the clubhouse) to the apparently very specific lifestyle of its inhabitants. Paralleling developments in Western countries, full-time working parents (and especially mothers) appear to lead lives that are more and more 'workrather than neighbourhood-orientated' (Lees, 2003 , p. 2507). To cater to their needs, a small kindergarten/pre-school is attached to the compound. School buses and taxis were bringing students home in the afternoons, and the children often paid a visit to the soup kitchen across the street (part G) before returning to their apartments. Adult residents of E, by the way, also commonly visited the soup kitchen, especially in the mornings, while waiting for their taxis, and in the evenings, when returning from work. Also popular were the fruits shop, the cigarette booth, and especially, as stated before, the wet market.

The ecomap (Figure 13) easily reveals that one specific actor on site functioned as the focal and connecting link between actors of most backgrounds (including myself): the sempstress (Figure 16). After arriving at her post opposite the gate to the compound at 0730 hours every morning, she would usually sweep 'her' part of the sidewalk, set up her mobile stand and remain there until sunset (at approximately 1830 hours). Next to her sewing machine, the sempstress would set up a little bench, suitable to sit on for two to three persons. During the day, customers would sit down while waiting for the completion of their orders. Besides, numerous individuals from the neighbourhoods would come by for a quick chat. Among them were the men of the 'Anhui-gang', several residents of $G$, anonymous passers-by, an elderly couple (they habitually went for walks every day at 0700 hours and

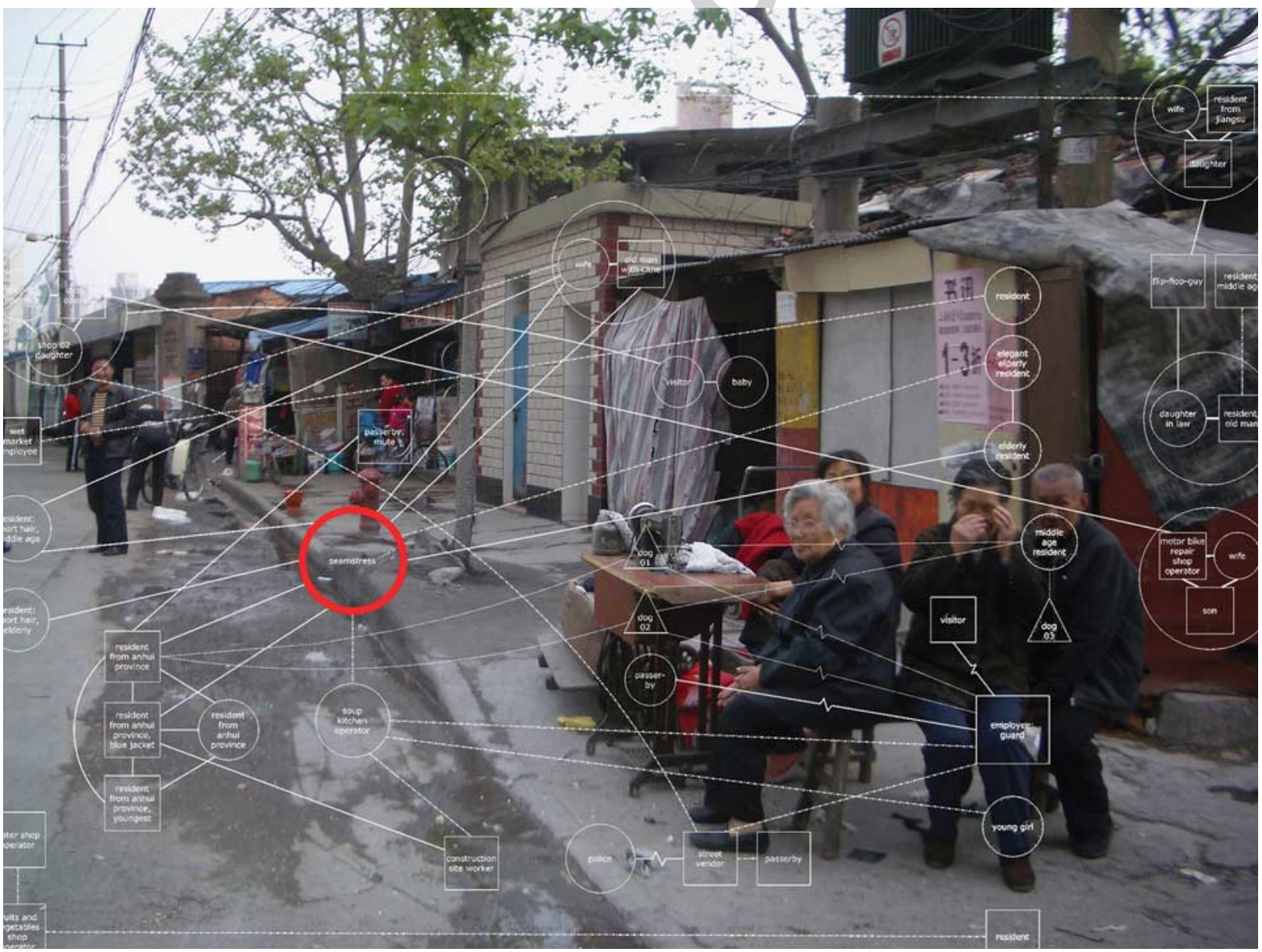

Figure 16: Linking actors of all backgrounds, a key figure: The sempstress. 
1500 hours, covering the joint line and parts G, E, $\mathrm{H}$ and $\mathrm{I}$ ), and - most surprisingly to me - at least two older ladies resident in the high-rises of part E. One of them would come down several times per day, making herself comfortable and chitchatting with the sempstress and other 'visitors'.

Contrary to their rather negative reputation on site, even the security guards (at the gate to E) appeared to maintain a loose, but friendly relationship with the sempstress. Guarding the compound often implied repelling 'unwanted' elements, be it dogs, drivers or individuals of any status. On several occasions, I witnessed how poor-looking individuals were ordered by the guards to walk around the compound, rather than using it as a short cut to part D.

Paralleling the position of the paid guards who work for the compound, I was able to detect another type of 'guards' on the borderland. Throughout the day, older (and less mobile) residents of $G$ would sit rather naturally on small chairs at junctions between the small alleys leading into the old neighbourhood (G), and the joint line. Most of the people entering the alleys would stop for a quick chat, and schoolchildren the own grandchildren as well as neighbours' children - would often sit next to the old people, doing homework or reading books.

As a last example for interaction taking place on the borderland, I would like to mention the liaison between the police and the 'flying vendors'. Obviously, vendors with stands inside the wet market and most of the little shops along the joint line collaborate with 'flying vendors' - individuals in possession of wheelbarrows and tricycles, which enable them to drive around in the neighbourhood and sell merchandise of all sorts. As apparently they are not permitted to do so officially, whenever one of the many patrolling police cars would come into sight, the 'flying vendors' would immediately pull into the narrow (and inaccessible for cars) alleys of part G, hiding

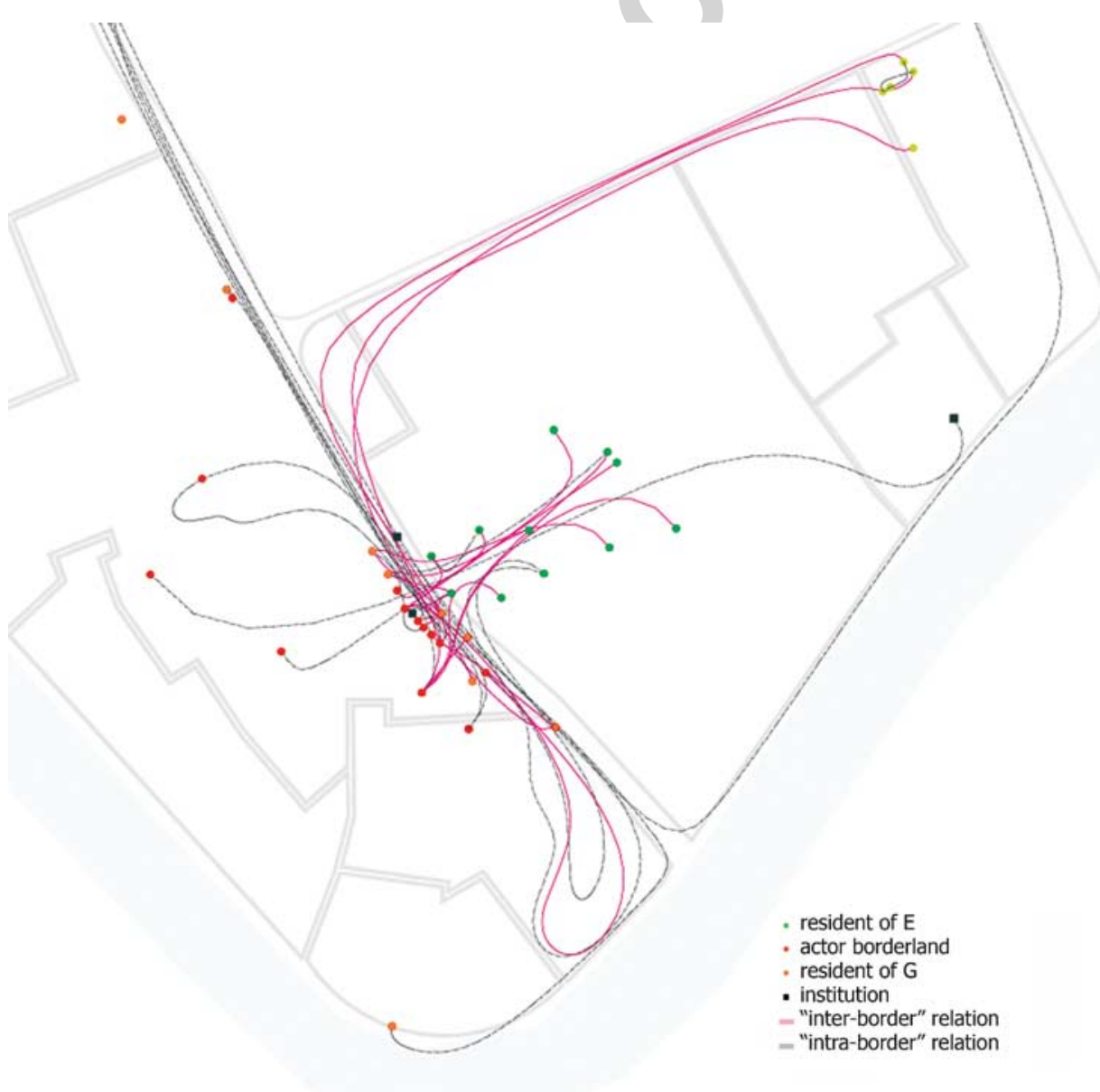

Figure 17: Socio-spatial interaction. 

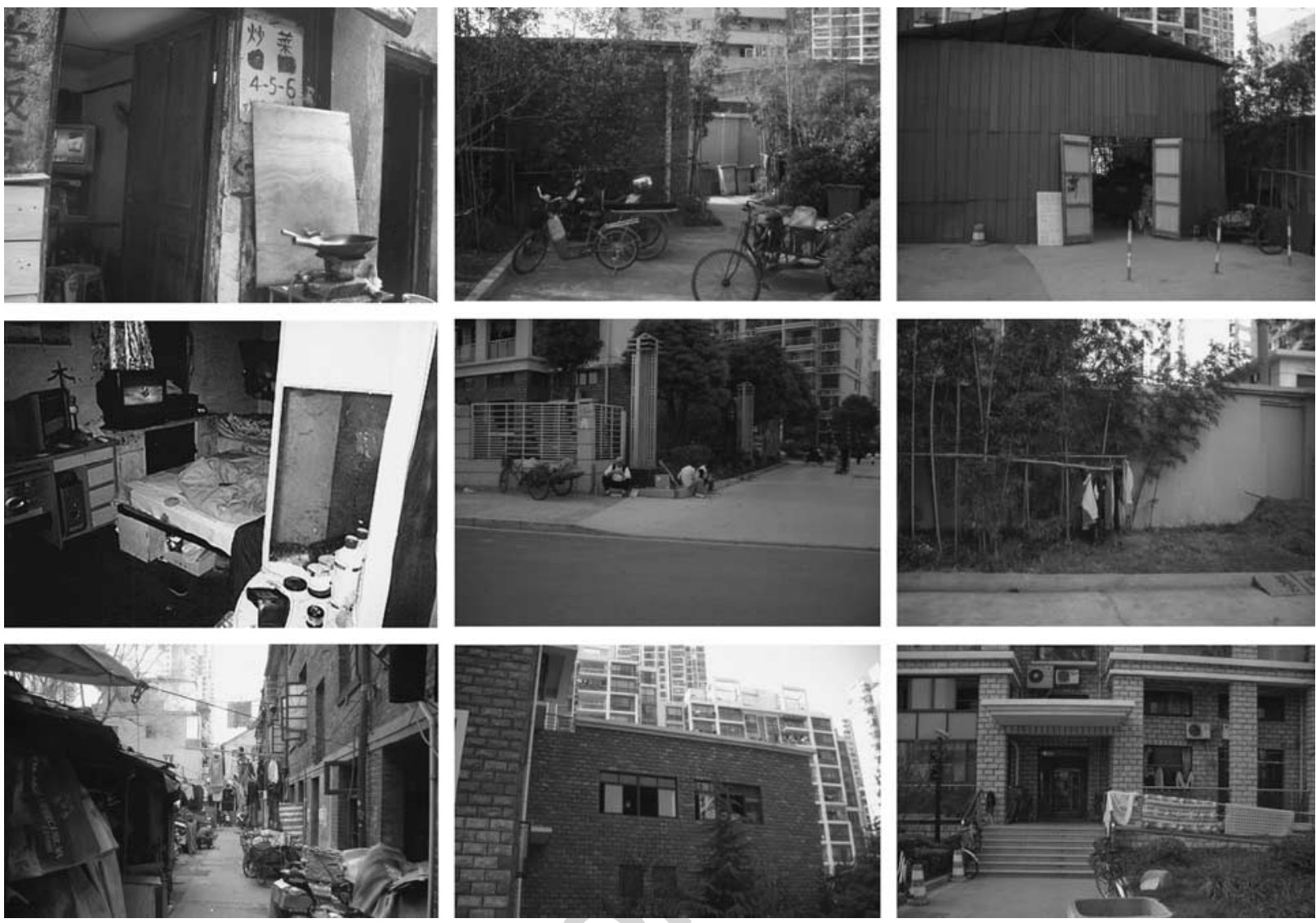

Figure 18: Traces of the 'other'.

there until the danger would pass. This game of cat-and-mouse would sometimes repeat up to 10 times per hour.

Figure 17 shows the spatial paths of actors and their interconnections (see Figure 13) within the context of the study site. It reveals a high level of 'inter-border' relations, the relations between actors of different background (here referring to their place of residence, distinguishing between parts E, G or the 'borderland', when none of the former applies), and across the borderline separating them. Despite the efforts to keep apart from the 'old' and 'other', we can see representatives of part E continuously interacting with representatives of the surrounding areas. Furthermore, even inside part E - a space so carefully fenced and guarded against its surroundings - the 'other' (the 'old' and the 'poor') becomes visible. Examples of this infiltration include laundry hung to dry around the landscaped areas of the compound (attributable to service personal employed); spaces rather informally occupied by representatives of the 'other' (for example, garbage rooms, ground floors of several high-rises - originally intended to accommodate services); residents of part G 'sneaking in' as to enjoy the green park inside the compound. As a counterbalance, we can easily find traces of the 'other' (now the 'new' and the 'rich') contrasting decrepit shacks, dotted within part G: TVs, cell phones and computers (Figure 18).

\section{Conclusions}

[...] the city $[\ldots]$ has been a place for creation and not simply a result, the simple spatial effect of a creative act that occurred elsewhere, in the Mind, or the Intellect. [...] the urban can become 'objective', that is, creation and creator, meaning and goal.

(Lefebvre, 2003, p. 28)

By introducing the case of a study site in Shanghai, this paper attempts to capture the peculiarities of spatial and temporal coexistence of (at least) three typical stages in urban development represented by complementary segments 
of urban fabric and socio-spatial settings. The borderlands or joint lines between those segments act as 'melting pots' for actors of different backgrounds. On the joint lines, inhabitants and users define space, turning public temporarily into private and then again, turning private temporarily into public. We have seen the strategy of fencing in order to 'purify space' (Sibley, 1995), to exclude the unwanted from the new residential compound, fail, in favour of a high degree of interaction and interconnectedness between the different segments, their inhabitants and users - even if often limited to merely economic exchange.

The two focal neighbourhoods in this paper the 'old' and the 'new' - represent and respond to different forces involved in the process of shaping the city. Among them are forces driving development 'from within' and 'from without'. More specifically, its inhabitants' struggle for survival manifests as one of the most important forces to affect pace and direction of progress for the old neighbourhood. Pushing outside the boundaries confining them, in an attempt to make the best use of the limited resources available to them, residents, for example, create their own rules concerning the interpretation of conventional terms such as property (and limits); they invent strategies for exchange and interaction with the shifting world surrounding them; they spontaneously re-create and re-define their environment according to their basic needs and momentary demands. Thus, they are the underlying cause of creation and expansion, the driving force 'from within'. On the contrary, inhabitants of the new residential compound appear rather content within their carefully demarcated 'antecedent boundaries' (if I am to borrow terminology from political geography). Those are the boundaries created prior to the establishment of their community, encircling a purpose-built environment designed by planning professionals; the boundaries created by forces of a larger-scale economy, dictated on a level far from that of the community, forces 'from without'. In many cases, the old, driven-from-within, eventually makes place for the new, driven-from-without; in others, it remains and continues to take effect, most explicitly by utilizing the very boundaries assigned to it. The (temporary) boundary between old and new, the joint line, is the spatial manifestation of collision between the differing forces.

For German philosopher Helmuth Plessner the human being exists in a framework of space.
'Positionality' describes the idea that a living organism is not a prisoner of his boundaries, but lives through them, continuously in the process of changing and redefining. It is through 'dynamic bordering', that the living organism relates to its environment. (Ernste, 2004, p. 443). For Plessner, 'bodily existence and human consciousness' do not establish dualism, but 'dual-aspectivity' 'two simultaneous and inseparable sides of the same being'. We cannot be 'either' - 'or', but we have to be both (Ernste, 2004, p. 444) - an idea, by the way, deeply engrained within the classic Chinese concept of 'yin and yang'. George Canguilhem, in a way paralleling this line of thought, later claimed that the healthy cannot exist without the pathological, comprehending crisis as a way to 'establish a new order' (Canguilhem, 1991, p. 200).

Urbanity, in the first instance within (yet not limited to) the notion of 'European urbanity' (Siebel, 2000), is based on the concept of coexistence and diversity of space, people and lifestyles. In this paper, I have attempted to draw an image of the contemporary Chinese city as one that manages to provide for the necessary niches to incorporate exactly that: coexistence and diversity. Despite the massive homogenizing forces at work under commodification and globalization, the poor, the old and the past remain integral parts of the city - in need of more effective strategies towards their integration, rather than eradication. The heterogeneity and fragmentation of urban space allows for people of most diverse backgrounds and with most diverse needs to create their livelihoods. The space that helps to build what is currently called for as the 'harmonious society' in which 'people at all levels respect each other' and maintain 'honest, friendly and harmonious relationships' as well as 'just, fair and open competition' (People's Daily Online, $2007 \mathrm{~b}, 29$ September) is where they meet, interact and mutually benefit from each other. It is the shared space in-between the complementary segments of the city, the joint line.

\section{Acknowledgement}

I thank Professor Tatsuro Sakano and Heide Imai for many inspiring conversations, Rolf Demmler for his invaluable support on countless occasions, and Prof. Fulong $\mathrm{Wu}$ and two anonymous reviewers for their constructive comments. 


\section{References}

Bangert, E., Charton, J. and Demmler, R. (2002) Recharging the different: London Lee Valley. Master thesis (not published), University of Darmstadt.

Canguilhem, G. (1991) The Normal and the Pathological. New York: Zone Books.

Eco, U. (2006) The Mysterious Flame of Queen Loana: An Illustrated Novel. Orlando, FL: Harvest Books-Harcourt Trade Publishers.

Ernste, H. (2004) The pragmatism of life in poststructuralist times. Environment and Planning A 36: 437-450.

Gaubatz, P. (1999) China's urban transformation: Patterns and processes of morphological change in Beijing, Shanghai and Guangzhou. Urban Studies 36: 1495-1521.

Lees, L. (2003) Super-gentrification: The case of Brooklyn heights, New York City. Urban Studies 40: 2487-2509.

Lefebvre, H. (2003) The Urban Revolution. Minneapolis, MN University of Minnesota Press.

Lu, H. (1995) Creating urban outcasts: Shantytowns in Shanghai, 1920-1950. Journal of Urban History 21: 563-596.

Marshall, R. (2004) Shanghai's waterfront - Presenting a new face to the world. In: P.G. Rowe and S. Kuan (eds.) Shanghai: Architecture \& Urbanism For Modern China. Munich, Berlin, London, New York: Prestel Publishing, pp. 160-171.

Marx, K. and Engels, F. (1968) Selected Works. London: Lawrence \& Wishart

Newman, D. (2003) On borders and power: A theoretical framework. Journal of Borderlands Studies 18: 13-25.

Newman, D. and Paasi, A. (1998) Fences and neighbours in the postmodern world: Boundary narratives in political geography. Progress in Human Geography 22: 186-207.

People's Daily Online. (2004) Relocation makes room for Shanghai World Expo. 9 November 2004, http://english. people.com.cn/200411/09/eng20041109_163230.html.

People's Daily Online. (2005) Relocation starts in Shanghai for World Expo venues. 11 April 2005. http://english.people. com.cn/200504/11/eng20050411_180476.html.
People's Daily Online. (2007a) Maglev extension given 'green light'. 9 May 2007, http://english.people.com.cn/200705/ 09/eng20070509_373122.html.

People's Daily Online. (2007b) Harmonious society. 29 September 2007, http://english.people.com.cn/90002/92169/ 92211/6274603.html.

Roberts, KD. (1997) China's tidal wave of migrant labor: What can we learn from Mexican undocumented migration to the United States? International Migration Review 31: 249-293.

Sibley, D. (1995) Geographies of Exclusion. London: Routledge. Siebel, W. (2000) Wesen und Zukunft der europäischen Stadt. DISP 141: 28-34.

Shanghai Daily Online. (2007) Bridges built for wide loads. 10 April 2007, http://www.shanghaidaily.com/sp/article/ 2007/200704/20070410/article_312098.htm.

Shanghai Fifth Population Census Office (SFPCO). (2002) Tabulation on Shanghai's Fifth Population Census. Shanghai, China: Shanghai People's Press.

Spiegel Online. (2007) Shanghai residents protest transrapid extension. 13 March 2007, http://www.spiegel.de/inter national $/ 0,1518,471442,00 . \mathrm{html}$.

van Houtum, H. and van Naerssen, T. (2002) Bordering, ordering and othering. Tijdschrift voor Economische en Sociale Geografie 93: 125-136.

Wang, YP. (2005) Urban Poverty, Housing and Social Change in China. London: Routledge.

Wu, F. (1998) The new structure of building provision and the transformation of the urban landscape in metropolitan Guangzhou, China. Urban Studies 35: 259-283.

Wu, F. (2001) Real estate development and the transformation of urban space in Chinese transitional economy: With special reference to Shanghai. In: J.R. Logan (ed.) The New Chinese City: Globalization and Market Reform. Oxford: Blackwell Publishing, pp. 151-166.

Wu, F. (2002) Sociospatial differentiation in urban China: Evidence from Shanghai's real estate markets. Environment and Planning A 34: 1591-1615. 